\title{
Economics and theology special issue: introduction
}

\author{
Luigino Bruni ${ }^{1} \cdot$ Paul Oslington $^{2} \cdot{\text { Stefano } \text { Zamagni }^{3}}^{3}$
}

Published online: 19 February 2016

(C) Springer-Verlag Berlin Heidelberg 2016

A new and promising debate between social sciences and theology is taking off. From the very beginning of Christianity up to modern political economy, crossfertilization between theology and oikonomia has occurred, sometimes to the extent that one constituted the other. For example, the economic notions of redemption and reconciliation are integral to the New Testament account of God's dealings with human beings. The early Christian theologians developed the idea of an economy of salvation. Smith, Marx, Vico, Genovesi, and others drew on theology, and their theoretical systems were influenced by theological debates (see Urquhart and Elias in this special issue).

Philosopher Walter Benjamin wrote in 1921 that "Capitalism is a religion, that is to say, capitalism essentially serves to satisfy the same worries, anguish, and disquiet formerly answered by so-called religion. Then, capitalism itself developed parasitically on Christianity in the West" (Benjamin 1986 [1921], p. 102). According to Benjamin, capitalism is a new form of religion that calls for an exclusive form of worship and replaces Christianity (not any religion), because it spawned from JewishChristian humanism (see Nelson 2010 and also Samir in this issue for a discussion of the interplay between economy and Islam). According to this view (that is consistent

Luigino Bruni

luigino.bruni@gmail.com; 1.bruni@lumsa.it

Paul Oslington

paul.oslington@ac.edu.au

Stefano Zamagni

stefano.zamagni@unibo.it

1 LUMSA University, Rome, Italy

2 Alphacrucis College, Sydney, Australia

3 University of Bologna, Bologna, Italy 
with Marx's vision of capitalism, less with Weber's: see Weber 1976; Fanfani 1934; Barbieri 2013; Oslington 2011, 2014), modernity is not characterized by a disenchantment of the world, but instead by the affirmation of a new religion, i.e., by the transformation of the Christian spirit into the "spirit" of capitalism. In modern times, the deep and crucial links of capitalism to the protestant ethics were a classic locus in sociology, and the issue of providence has been central not only in Adam Smith but also in the foundations of the whole modern political economy, from the Neapolitan G. Vico to the French Physiocrats or la sect de les économists, as first underlined by Viner (1972) and Hirschman (1977). In the tradition of political economy after Smith there have been economists with strong theological interests, i.e. the English Wicksteed (1885, 1910) or the Italian Sella (1930).

Moving from the realm of ideas to actual economies in general, the intertwined relations between Christianity and capitalism run deep. Capitalism borrows from the vocabulary of the Bible (faith-trust, credit-belief). And we cannot understand the Middle Ages, the Reformation or Modernity, unless we take into account the numerous intersections between grace and money.

A key period in the interconnections between theology and the economy is the protestant Reformation and the Catholic Counter Reformation (Controriforma) in the XVI-XVII centuries. Before this crucial crossroad of Western civilization, market economy had growth as a unique European movement, from Sicily to London, from Lisbon to Prague. Christian faith had represented the new philia (fides) that, as in the polis of Aristotle and Pericles, made possible trust and trading among different people belonging to different clans and villages. The fiere along the big rivers of Europe were the hubs of complex networks of commercial, artistic, and cultural relationships that sprung into the Civic Humanism and Rinascimento of XV and XVIII centuries. The scholastic philosophers and theologians-Aquinas over all, for his huge influence over the second Middle Age social, philosophical, and economic syntheses-have built up a first ethics of the proto-market economy based on the pivotal idea of common good, namely the thesis that the good of the individual has to be seen in deep and necessary connection with the good of the community. From that vision came a conception of economy-money, usury, just price ...-ontologically communitarian and hierarchical, because the mediators (priest, king, father ...) were the basic mechanism to implement the harmonization of public and private goods. Furthermore, in the late Middle Age, the connections between market and religion have reached a very huge dimension: indulgences, poor people paid by the rich ones for making prayers and penitence in their place, donation of bankers for buying reduction of years of purgatory, etc.

Martin Luther reacted against at least two elements of the southern Christianity: (a) the excessive and often insane mixture money-grace, (b) the magnificence of Rome and Italy that were also the fruit of the wealth created by a new and positive attitude toward luxury and money during the XIV and XV centuries. Luther was deeply impressed and shocked by the mundane and market-based society he met in Italy that considered far from the original message of austerity and poverty of the gospel. The strong reaction of Lutheran and later Calvinist Reformation was against not only the theology of the Roman church, but also against the style of living of Italian Renaissance, its palaces, masterpieces of art, Michelangelo, Leonardo. Therefore, the 
protestant cultural program was also a reestablishment of a more authentic and less money-oriented society, but, paradoxically, due to the elimination of the hierarchical mediation of the church, the protestant culture created an environment much more adapt to develop the capitalist economy (Magatti and Martinelli, in this issue; see also Barbieri 2013). In fact, while in southern Europe the counterreformation stopped the process of freedom in commerce and politics started with the civic humanism, in the northern protestant countries the individual freedom (produced by the elimination of hierarchy of the church) was the engine of capitalistic revolution. Then was the northern protestant Europe where the civic humanism and renaissance tradition continued, although in Roman Catholic countries, such as Italy or Spain, there was a re-feudalization of the society that brought back those countries into a situation close to the Middle Age before civic humanism.

The mediation of the Roman Catholic church is a very key point here. Unlike the protestant world, in the Roman context the church and its institutions played a central role in the legislation regarding commerce and money, using a theological vision - that of the Scholastic, of Aquinas in a special way-written in a different historical period (centuries XIII-early XIV) more static and based upon Aristotelian categories (sterility of money, ...) that in the Rinascimento were not anymore able to encompass the new economic reality after commercial revolution of the Italian and European cities. As underlined in the early XVIII century also by Scipione Maffei, the mediation and control of the institutions of the Catholic church upon individual economic activity, and the strong tools of implementation of this control (i.e., Inquisitione), made the countries of South Europe (Italy, Spain, Portugal, part of the France) in a condition of economic and financial disadvantage with respect to Northern Europe. In fact, due also to a lack of religious hierarchy, in Holland and in the other protestant countries, financial and money lending were allowed, and so commerce and wealth growth (Barbieri 2013). Parallel to this, whereas in the North Europe and later in USA, thanks to Calvinist ethics, labor and business were considered to be moral ways of engaging in ordinary life, in Italy after the Controriforma there was a re-feudalization of the culture, with a new praise for rural life and diffidence toward urban life (and its commerce). Also the condemnation of money lending and usury knew a new season in Italy in the Seicento that contrasts with what was going on in northern part of Europe-Bentham "defence of usury" is a radicalization of a widely shared idea in this context. It is true that most ecclesiastic, political thinkers, theologians of the post-Controriforma season were laudatores of labor, but the praised labor was agricultural and intellectual work, whereas the manual or artisan's activity in the cities (smiths, carpenters, shoemakers, ...) was considered to be not noble and servile.

Most of the present-day differences in labor culture, public debt, private and public ethics, in welfare states, individual rights, and the idea of market lay in the two different ways that Europe took after the Reform and Controriforma era. The Cinquecento and Seicento were therefore a return to Middle Age (Aquinas) as far as economic ethics is concerned. The modernization and openness to market of Quattrocento, with the key role of figures such as Bernardino da Siena or Leon Battista Alberti, were not able to fully flourish in Italy and Southern Europe. Second, the age of Controriforma was-with few exception, such as Menochio-a 
praise of agriculture and rural life and a criticism to urban and civic activities (i.e., commerce). As a consequence, starting with the second half of XVI century, Latin Europe knew a re-feudalization of society and a centrality of rent over profit of merchants and salary of workers. Third, after Reformation, neo-Platonic thought replaced the Aristotelian one of the Quattrocento; then, solitude, esoteric, and magic practices took the place of social and political activities of the Aristotelian vision of Leonardo Bruni and other civil humanists of the previous century. A thesis consistent with that of the historians Eugenio Garin and Hans Baron, who almost in the invented the expression of Civic Humanism in order to distinguish the (first half) of Quattrocento.

Finally, an issue that is present in particular in Martinelli and Magatti paper is the key role of theology for understanding the still relevant differences between the Anglo-Saxon capitalism and the Latin European one. The southern Europe, its long history characterized by a huge biodiversity, at the apex of Middle Age had generated a market economy based on Catholic paradigm and then expression of a communitarian and institutionally "mediated" idea of society. The northern protestant traditions gave life to an idea of society of individuals without the mediation of intermediate institutions, i.e., the humanism of the "invisible hand" and of the Leviathan: within the space of freedom of the State Leviathan created by the social contract, the common good is not entrusted to the mediation of the institutions but is the non-intentional result of the actions of separated and independent individuals. The Reformation and the Controriforma have been a turning point in the Modern Europe, and the contemporary gaps in economic and social terms between North and South Europe are fruits of an interrupted path. The social pathologies, the "amoral familism," and the corruption of "mediated society" of the Italian and Mediterranean societies are well known and serious. At the same time, also the protestant humanism, its individualism, is facing a different but not less relevant crisis that calls for something new too (Milbank and Pabst in this issue).

We hope that in this transition age of capitalism, this special issue can offer some light for a deeper understanding of our time.

We dedicate this special issue to Pier Luigi Porta, Editor in chief of this journal, organizer of the Conference on "Economic Theology, theological Economics" (Rome, May 2014), where the papers of this special issue were first presented. Pier Luigi was an exceptionally talented historian of economics, a dear friend and beloved colleague. His death came when this issue was about to be completed. With the hope that he would have been pleased with our work.

\section{References}

Barbieri G (2013)[1940] Decline and economic ideals in Italy in the early modern age. Leo S. Olschki, Florence

Benjamin W (1986) Capitalism and religion. In: Liedemann R, Hermann (eds) Gesammelte Schriften, vol VI. Suhrkamp Verlag, Schweppenhäuser, Frankfurt 
Fanfani A (1934) Cattolicesimo e protestantesimo nella formazione storica del capitalismo. Vita e Pensiero, Milan. Translated as Catholicism, Capitalism and Protestantism

Hirschman AO (1977) The passions and the interests. Political arguments for capitalism before its triumph. Princeton University Press, Princeton

Nelson RH (2010) Two gods: economic religion versus environmental religion. Pennsylvania State University Press, Pennsylvania

Oslington P (2011) Adam Smith as theologian. Routledge, London

Oslington P (ed) (2014) Oxford handbook of christianity and economics. Oxford, OUP

Sella E (1930) La dottrina dei tre principi. Cedam, Padova

Viner J (1972) The role of providence in the social order. American Philosophical Society, Philadelphia Weber M (1976) The protestant ethic and the spirit of capitalism (trans: Parsons T). Allen and Unwin, London

Wicksteed PH (1885) Is christianity practical?. Lindsley Press, London

Wicksteed PH (1910) The commonsense of political economy. Macmillan, London 